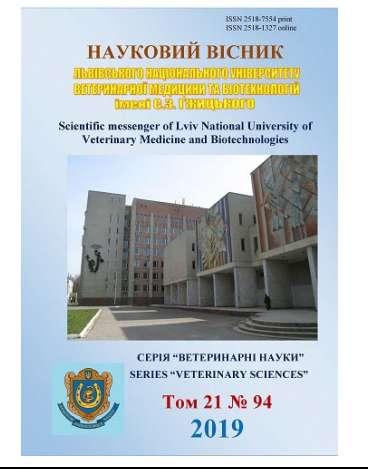

\author{
Науковий вісник Дьвівського національного університету \\ ветеринарної медицини та біотехнологій імені С.З. Гжицького. \\ Серія: Ветеринарні науки \\ Scientific Messenger of Lviv National University \\ of Veterinary Medicine and Biotechnologies. \\ Series: Veterinary sciences
}

UDC 637.56.055:615.9

\title{
Study of toxicness of snails meat on biological model
}

\author{
I.S. Danilova
}

National Scientific Center “Institute of Experimental and Clinical Veterinary Medicine”, Kharkov, Ukraine

\section{Article info}

Received 02.04.2019 Received in revised form 01.05 .2019

Accepted 02.05.2019

National Scientific Center "Institute of Experimental and Clinical Veterinary Medicine", Pushkinskaya Str., 83, Kharkov, 61023, Ukraine. Tel.: +38-067-305-93-51 E-mail:irrulik@meta.ua
Danilova, I.S. (2019). Study of toxicness of snails meat on biological model. Scientific Messenger of Lviv National University of Veterinary Medicine and Biotechnologies. Series: Veterinary sciences, 21(94), 57-60. doi: 10.32718/nvlvet9410

Snails can be found in any part of the planet. They belong to the class of gastropods, which includes terrestrial, freshwater, marine snails. Their ancestors are some of the most ancient species of the fauna. Archaeologists say that the first lived on our planet 500 million years ago. There are about 90000 species of snails, but only 3 species have gained worldwide fame: gigantic African snail, grape and Helix aspersa. Snail's meat improves bowel function and normalizes metabolism. It is believed that due to the content of magnesium, snail meat has calming effect on humans and helps to fight stress. To determine the level of toxicity of food snails meat on a biological model. Helix pomatia snails were collected in wet weather, after rain or in the morning, Helix aspersa maxima and Helix aspersa muller were recieved from the farm "SNAIL 2016" (Ukraine). As a model we used white mise. To determine the toxicity, the sampled meat preparation has been conducted. For this purpose an average sample of meat of each snail types of $10.0 \mathrm{~g}$, carefully chopped. The milled sample of $5.0 \mathrm{~g}$ was introduced into a sterile glass, poured $50.0 \mathrm{~cm}^{3}$ of distilled water, stirred and filtered. There were formed experimental 6 and 2 control groups of mice were formed by six in each one, of 2 months of age (body weight $20 \mathrm{~g}$ ). Subsequently, prepared samples of snails meat were injected into the mice stomach through a probe every day for 3 days by $0.5 \mathrm{~cm}^{3}$. As a probe, a thin, single-use micropipette was used. The white mice of each group experimental of all groups were placed in isolated cages and clinically monitored for five days. The mice didn't recieved food, animals had free access to water. Mice of the control groups had free access to food. The meat of each type of snails in the experiments was used both fresh and after 7 days storage refrigerator at a temperature of $4{ }^{\circ} \mathrm{C}$. It was found that filtrates from fresh meat of the three types of food snails Helix aspersa maxima, Helix aspersa muller and Helix pomatia were non-toxic, for the mice of I, II and III groups. We have noticed that the meat that was stored for 7 days in the refrigerator at a temperature of $4{ }^{\circ} \mathrm{C}$ was toxic. Mice of the V-VII groups that were fed such meat had a depressed state, muscle tremor, they refused of water and died on $2^{\text {nd }}$ and $3^{\text {rd }}$ days. The mise of control groups (IV and VIII) remained during all experience remained living. This work can be used as a method for determining the toxicity of snail's meat. It is technologically simple, it requires only laboratory animals, namely white mice, does not require special equipment. Only 3 days can get the result. The method can be used in the work of scientific-experimental, production and regional laboratories of veterinary medicine.

Key words: white mise, snail, meat, toxicity.

\section{Вивчення токсичності м'яса равликів на біологічній моделі}

\author{
І.С. Данілова
}

Національний науковий центтр “Інститут експериментальної і клінічної ветеринарної медицини”, м. Харків, Украӥна

Токсичність (від грец. toхіkоп - отрута) - отруйність, властивість деяких речовин біологічної природи при потраплянні в певних кількостях у живий організм (людини, тварини і рослини) викликати порушення його фізіологічних функцій, в результаті чого виникають симптоми отруєння (інтоксикації, захворювання), а при важких - загибель. Равлики за правильного приготування не 
мають протипоказань, якщчо, звісно, не враховувати індивідуальну непереносимість. Якщо вона буде виявлена, то краще виключити зі свого рачіону ией продукт. Але питання щзодо вивчення токсичності м'яса равликів на сьогодні залишається мало дослідженим. Викладено дані шодо токсичності м'яса равликів: Helix aspersa maxima, Helix aspersa muller ma Helix poтаtia. При иьому випробували біологічний метод на білих мишах. Встановлено, ичо м'ясо трьох видів равликів, яке зберігалося протягом 7 діб в умовах холодильної камери холодильника за температури $+4{ }^{\circ} \mathrm{C}$, не придатне для вживання, $\epsilon$ не свіжим $і$ токсичним. $У$ білих мишей, яких годували фільтратом з такого м'яса спочатку спостерігали пригнічений стан і тремор м'язів, скуйовджену иерсть, відмову від пиття, а потім і загибель на 2 та 3 добу. Протягом усього досліду миші мали пригнічений стан. Відмічено, щзо дану роботу можна використовувати в лабораторіях ветеринарної медицини як спосіб визначення токсичності м'яса равликів.

Ключові слова: білі миші, равлик, м'ясо, поксичність.

\section{Вступ}

Равликів можно зустріти, в будь-якому куточку планети, а за кількістю видів вони поступаються тільки комахам. Належать до класу черевоногих, який включає в себе наземних, прісноводних, морських равликів та слимаків. Їх предки - одні з найдавніших видів тваринного світу. Археологи говорять, що перші черевоногі жили на нашій планеті ще 500 мільйонів років тому (Babalola \& Akinsoyinu, 2009).

У Німеччині в перші століття християнства ченці намагалися розводити равликів при монастирях у садах, засаджених капустою. Равлики вважалися стратегічним запасом на випадок голоду і цінувалися як заміна м'яса в піст (Shevchuk et al., 2011).

В Україні доволі інтенсивно споживали равликів у трипільський період, а також під час голодомору в 1932-1933 рр. та у важкий післявоєнний період 19451948 pp.

У сучасному світі роль равликів зазвичай обмежується використанням у кулінарії. Але так було не завжди. В минулому деякі народності вважали черевоногих “нечистими” тваринами, від яких немає ніякої користі. Для стародавніх вавилонян і египтян равлики були символом вічності, а ацтеки взагалі боготворили цього молюска - вважали його богом місяця (Malik et al., 2011). Перші відомості про вживання цих черевоногих в їжу належить до часів античності. Відомо, що стародавні римляни не гидували равликами, і це багате протеїнами м'ясо однаково часто з'являлося на тарілках знаті й бідняків.

Існує біля 90000 видів равликів, але всесвітня слава дісталася лише 3 видам: гігантському африканському равлику, виноградному і Helix Aspersa.

У наш час Україна виходить на передове місце в Європі за експортом їстівних равликів. Постає питання щодо створення спеціалізованих ферм з розведення цих черевоногих молюсків. Природа надзвичайно щедро наділила м'ясо равликів багатьма вітамінами. Також воно містить дуже корисну для мозку людини амінокислоту - холін. Ще до складу м'яса равликів входять цінні мікро- і макроелементи: залізо, цинк, селен, кальцій, натрій. Неймовірно багаті ці черевоногі молюски магнієм, калієм, фосфором і міддю. Всі елементи $є$ в легкозасвоюваній людиною формі. М'ясо равликів м'яке, воно легко засвоюється і розщеплюється.

Так, наприклад, якщо на перетравлення свинини або курятини зазвичай в середньому потрібно 45 годин (Paska \& Masliichuk, 2017), то на перетравлення м'яса равликів досить і 2 годин.
Равликів особливо рекомендують тим, у кого є порушення кальцієвого балансу в організмі, вагітним і жінкам, що годуюють, дітям і людям, які страждають такими захворюваннями, як хондроз і коллагеноз.

М'ясо равликів поліпшує роботу кишківника і нормалізує обмін речовин.

Вважають, що завдяки вмісту магнію, м'ясо равликів здатне впливати заспокійливо на людей і допомагає боротися зі стресом.

Равлики за правильного приготування не мають протипоказань, якщо, звісно, не враховувати індивідуальне несприйняття. Якщо воно буде виявлене, то краще виключити зі свого раціону цей продукт.

Але питання щодо вивчення токсичності м'яса равликів на сьогодні залишається малодослідженим.

Токсичність (від грец. toxikon - отрута) - отруйність, властивість деяких речовин біологічної природи при потраплянні в певних кількостях у живий організм (людини, тварини і рослини) викликати порушення його фізіологічних функцій, в результаті чого виникають симптоми отруєння (інтоксикації, захворювання), а при важких - загибель (Kovbasenko et al., 2014).

Мета роботи. Визначити токсичність м'яса харчових равликів на біологічній моделі.

\section{Матеріал і методи досліджень}

Равликів виду Helix pomatia збирали у сиру погоду, після дощу, або вранці, Helix aspersa maxima та Helix aspersa muller були отримані 3 фермерського господарства "РАВЛИК 2016" (Україна). Як моделей ми використовували білих мишей.

Для визначення токсичності спочатку робили пробопідготовку м'яса. Для цього брали середню пробу м'яса кожного виду равлика вагою 10,0 г, ретельно подрібнювали в ступці. Подрібнену пробу вагою 5,0 г вносили у стерильну склянку, заливали $50,0 \mathrm{~cm}^{3}$ дистильованої води, перемішували і фільтрували.

Для досліду ми відібрали 48 білих мишей 2місячного віку з масою тіла від 19 до 22 г. Надалі нами сформовано вісім груп, 3 яких шість дослідних груп та дві котрольні групи по шість мишей у кожній.

Потім проводили безпосередньо дослід, для цього зразки, які були підготовлені за описаною нами методикою, вводили мишам у шлунок через зонд кожного дня упродовж 3-х днів по 0,5 cм ${ }^{3}$. Як зонд використовували тонку одноразову мікропіпетку. Білих мишей кожної групи розміщували в ізольовані клітки і проводили клінічне спостереження впродовж п'яти діб. Мишей залишали без їжі, а води давали вволю. 
Мишей контрольних груп забезпечували звичайним раціоном зерносуміші і давали воду вволю.

М'ясо кожного виду равликів в дослідах використовували як свіже, приготовлене еx tempore, так і не свіже, що зберігалося протягом 7 діб в умовах холодильної камери холодильника за температури $+4{ }^{\circ} \mathrm{C}$. Всі проби м'яса попередньо досліджували удосконаленими нами реакціями щодо визначення свіжості (реакція з реактивом Неслера та з сульфатом міді).
У роботі з тваринами дотримувались положень Європейської конвенції, прийнятої у Страсбурзі (1986 p.).

\section{Результати та їх обговорення}

Проведені нами дослідження щодо токсичності м'яса харчових равликів на білих мишах наведені в таблиці 1 .

Таблиця 1

Результати досліджень м'яса равликів на токсичність, $\mathrm{n}=48$

\begin{tabular}{|c|c|c|c|c|}
\hline \multirow{2}{*}{$\begin{array}{c}\text { № } \\
\text { особини }\end{array}$} & \multicolumn{3}{|c|}{ Вид равлика } & \multirow{2}{*}{$\begin{array}{l}\text { Контроль } \\
\text { (IV група) }\end{array}$} \\
\hline & $\begin{array}{c}\text { Helix aspersa maxima } \\
\text { (I група) }\end{array}$ & $\begin{array}{l}\text { Helix aspersa muller } \\
\text { (II група) }\end{array}$ & $\begin{array}{l}\text { Helix pomatia } \\
\text { (III група) }\end{array}$ & \\
\hline 1 & 2 & 3 & 4 & 5 \\
\hline & \multicolumn{4}{|c|}{$\mathrm{c} / \mathrm{M}$} \\
\hline 1 & з/ж & з/ж & 3/ж & 3/ж \\
\hline 2 & з/ж & з/ж & 3/ж & з/ж \\
\hline 3 & з/ж & з/ж & 3/ж & 3/ж \\
\hline 4 & з/ж & з/ж & з/ж & з/ж \\
\hline 5 & з/ж & з/ж & з/ж & з/ж \\
\hline \multirow[t]{3}{*}{6} & 3/ж & 3/ж & 3/ж & 3/ж \\
\hline & \multicolumn{4}{|c|}{$\mathrm{H} / \mathrm{M}$} \\
\hline & $\begin{array}{c}\text { Helix aspersa maxima } \\
\text { (V група) }\end{array}$ & $\begin{array}{c}\text { Helix aspersa muller } \\
\text { (VI група) }\end{array}$ & $\begin{array}{c}\text { Helix pomatia (VII } \\
\text { група) }\end{array}$ & $\begin{array}{c}\text { Контроль } \\
\text { (VIII група) }\end{array}$ \\
\hline 7 & 3/Д2 & $3 /$ Д2 $_{2}$ & $3 /$ Д2 $_{2}$ & 3/ж \\
\hline 8 & 3/Д3 & 3/Д3 & 3/Д3 & 3/ж \\
\hline 1 & 2 & 3 & 4 & 5 \\
\hline 9 & 3/Д2 & 3/Д2 & 3/Д2 & з/ж \\
\hline 10 & 3/Д3 & 3/Д3 & 3/Д3 & 3/ж \\
\hline 11 & 3/Д2 & 3/Д2 & 3/Д3 & з/ж \\
\hline 12 & 3/Д3 & 3/Д2 & 3/Д2 & 3/ж \\
\hline
\end{tabular}

Примітка: с/м - свіже м'ясо, н/м - несвіже м'ясо, з/ж - залишилася протягом досліду жива, з/дп - загинула на добу після зараження

За результатами таблиці 1 встановлено, що фільтрат зі свіжого м'яса трьох видів харчових равликів Helix aspersa maxima, Helix aspersa muller та Helix pomatia, який отримували штучно білі миші, виявився нетоксичним, а миші I, II та III груп залишилися живими протягом усього досліду.

Нами відмічено, що м'ясо, яке зберігалося протягом 7 діб в умовах холодильної камери холодильника за температури $+4{ }^{\circ} \mathrm{C}$ виявилося несвіжим і токсичним. Миші V-VII груп, що годувалися таким м'ясом, спочатку мали пригнічений стан і тремор м'язів, скуйовджену шерсть, відмовлялися від пиття та гинули на 2 та 3 добу.

Миші контрольних груп (IV та VIII) протягом всього досліду залишалися живими.

\section{Висновки}

Таким чином, можна стверджувати, що м'ясо равликів, яке зберігалося протягом 7 діб в умовах холодильної камери за температури $+4{ }^{\circ} \mathrm{C} \epsilon$ не свіжим i навіть токсичним для білих мишей. Дану роботу можна використовувати як спосіб визначення токсично- сті м'яса равликів. Він є технологічно нескладним, вимагає лише лабораторних тварин, а саме білих мишей. Не потребує спеціального обладнання. Строк отримання результатів складає лише 3 доби. Спосіб може бути використаний в роботі науковоекспериментальних, виробничих та регіональних лабораторіях ветеринарної медицини.

Перспективи подальших досліджень. Проведення гістологічних досліджень органів, які було відібрано від мишей, та визначення змін в них за рахунок токсинів м'яса.

\section{References}

Babalola, O. \& Akinsoyinu, A. (2009). Proximate composition and mineral profile of snail meat from different breeds of land snail in Nigeria. Pakistan Journal of Nutrition, 8(12), 1842-1844. doi: 10.3923/pjn.2009.1842.1844.

Kovbasenko, V.M., Khimych, M.S., Naidich, O.V., Pchelinska, L.V., \& Baran, M.M. (2014). Sposib vyznachennia toksychnosti ryby. Patent na korysnu model № 96714; zaiavl. 19.09.2014; opubl. 
10.02.2015, Biul. № 3. http://uapatents.com/4-96714sposib-viznachennya-toksichnosti-ribi.html Ukrainian).

Malik, A., Aremu, A., Bayode, G., \& Ibrahim, B. (2011). A nutritional and organoleptic assessment of the meat of the giant African land snail (Archachatina maginata swaison) compared to the meat of other livestock. Livestock Research for Rural Development, 23(3). http://www.lrrd.org/lrrd23/3/mali23060.htm.

Paska, M.Z., \& Masliichuk, O.B. (2017). Vyznachennia toksychnosti liupynovoho boroshna i dyvosylu ta funktsionalnykh kotlet z yikh vmistom. Naukovyi visnyk Lvivskoho natsionalnoho universytetu veterynarnoi medytsyny ta biotekhnolohii imeni S. Z. Gzhytskoho, 19(75), 35-39. doi: 10.15421/nvlvet7507 (in Ukrainian).

Shevchuk, V.F., Burlaka, V.A., Kryvyi, M.M., Mamchenko, V.Yu. (2011). Bezpeka ta sanitarna yakist miasa slymakiv pry yikh utrymanni $\mathrm{v}$ umovakh promyslovoi fermy. Visnyk ZhNAEU, 2(1), 158-163 (in Ukrainian). 